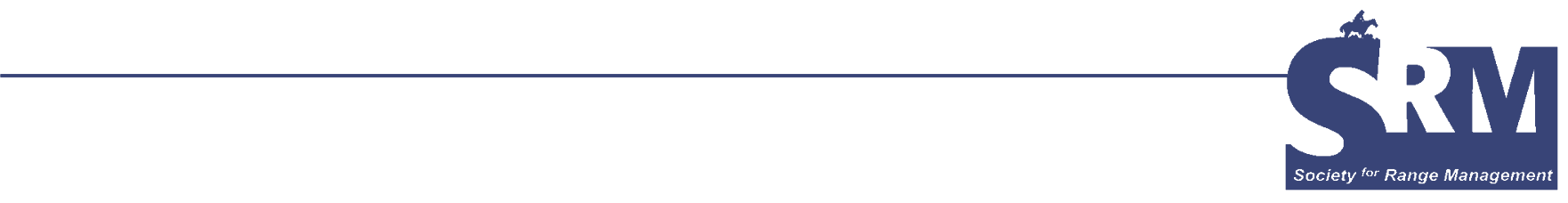

\title{
The Past Is Linked to the Present in Nevada
}

\section{By Liz Warner}

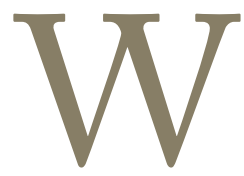
our dinosaur fossils and living prehistoric fish, the cui-ui; our ghosts and ghost towns; and our wild horses that some people call living legends.

Long before mankind inhabited Nevada, Ichthyosaurs, prehistoric marine reptiles, swam in the ocean that covered the land. Ichy's lived at about the same time as the dinosaurs, and their fossils are found on all continents except Antarctica. Of all the Ichthyosaurs discovered, the fossils at Nevada's Berlin-Ichthyosaur State Park are among the largest specimens known, reaching 50 feet in length.

The cui-ui, a prehistoric fish, is found only in Pyramid Lake north of Reno. The cui-ui once flourished in Pyramid Lake, where it was one of the main foods of the Paiute people.

Maybe ghosts are more to your liking than ancient fish. We can't promise you'll see a ghost, but we can tell you where to look. Visit Virginia City, for starters. Just a short 30 minutes south of Reno, Virginia City was one of the greatest mining camps in the world. The site of the Comstock Lode discovery in 1859, Virginia City was home to over 20,000 people in the mid-1870s. Today, Virginia City is a living "ghost town" with its historic downtown largely untouched by modern influences. A visit to St. Mary's Art Center, the former hospital and orphanage, will make the hair stand up on the back of your neck.

Many of the buildings in Carson City, the state and territorial capital, are haunted. Carson City has a large historic dis- trict that has become legendary. You can see the home where Mark Twain was "born"-literally. Samuel Clemens worked for his brother at the state legislature while writing for the Territorial Enterprise newspaper in Virginia City, and he took the pen name of Mark Twain to keep his identity secret.

If you're not into ghosts, wild horses are a part of $\mathrm{Ne}-$ vada's culture and a longtime source of argument. Whether you agree with their protection or not, there's nothing like seeing animals roaming free. Nevada has one of the largest populations of wild horses, and if you're lucky, you can see some within a short drive from Reno. If you're not feeling lucky, join the tour to the Bureau of Land Management's Wild Horse Facility in Palomino Valley.

And no article on Nevada culture would be complete without mentioning our visitors from outer space. Area 51 in southern Nevada has long been a favorite spot for alien visits, and the Little Ale'in in Alamo has pictures to prove it.

There's much more of Nevada's culture that I don't have room to cover here. One of the "tours" offered during the SRM meeting is Basque dining at one of Reno's oldest and authentic Basque restaurants. Or you can always visit the Nevada Railroad Museum or the new Native American $\mathrm{Mu}-$ seum when you're in Carson City.

You'll find a lot more about Nevada's culture on the State of Nevada's official Web site under the Department of Cultural Affairs (http://dmla.clan.lib.nv.us/).

We hope you'll take some extra time when you're at the conference to explore Nevada or come back later and stay longer. You're sure to enjoy all that Nevada has to offer.

Author is Public Affairs Specialist, Natural Resources Conservation Service, Reno, NV89502, liz.warner@nv.usda.gov. 